\title{
Ion Accumulation and Distribution in Shoot Components of Salt-stressed Eucalyptus Clones
}

\author{
C.M. Grieve ${ }^{1}$ and M.C. Shannon ${ }^{2}$ \\ U.S. Department of Agriculture, Agricultural Research Service, U.S. Salinity Laboratory, 450 W. Big \\ Springs Road, Riverside, CA 92507-4617
}

AdDitional Index words. drainage water reuse, Eucalyptus camaldulensis, E. rudis, ion distribution, ion exclusion, ion uptake, salinity

\begin{abstract}
Four clones of Eucalyptus camaldulensis Dehn. (4543, 4544, 4573, and 4590) and one clone of E. rudis Endl. (4501) were grown in greenhouse sand cultures irrigated with waters designed to simulate saline drainage waters present in the San Joaquin Valley of California, and compositions that would result from further concentration of the waters . The drainage waters are typically high in $\mathrm{Na}^{+}, \mathrm{SO}_{4}{ }^{2-}, \mathrm{Cl}^{-}$, and $\mathrm{Mg}^{2+}$. Electrical conductivities of the solutions were 2, 12, and $28 \mathrm{dS} \cdot \mathrm{m}^{-1}$. Ion uptake and distribution patterns in above-ground components were studied in members of these clones grown under treatment for 7 weeks. Results indicated the clones could be separated into two distinct groups by significant differences in leaf-ion relations. Group 1 clones 4543,4544 , and 4573 accumulated less $\mathrm{Na}^{+}$and more $\mathrm{Ca}^{2+}$ and $\mathrm{Cl}^{-}$in leaves than group 2 clones, 4501 and 4590 . Group 2 clones accumulated $\mathrm{Na}^{+}$under low salinity, but apparently possessed some mechanism for restricting $\mathrm{Na}^{+}$accumulation by the leaves that was activated as salinity increased. Leaf and stem $\mathrm{Cl}^{-}$ concentrations tended to be lower in all clones grown at $28 \mathrm{dS} \cdot \mathbf{m}^{-1}$ than at $2 \mathrm{dS} \cdot \mathrm{m}^{-1}$, despite increases in $\mathrm{Cl}^{-}$concentration in the irrigation waters. Under saline conditions, $K^{+}$and $P$ were preferentially accumulated in the youngest leaves in the upper portion of the canopy, whereas $\mathrm{Na}^{+}, \mathrm{Ca}^{2+}$, and $\mathrm{Mg}^{2+}$ were retained in the older leaves.
\end{abstract}

Distribution of mineral ions within the plant emphasizes the relative importance of various tissues and organs in the storage of both nutrient and toxic ions. Differences among mineral nutrients in their distributional patterns generally reflect differences in their physiological roles and functions as well as their relative mobility within the plant (Dell, 1996; Marschner, 1995). Gradients in mineral ion partitioning are also strongly dependent on age of the tissue. For example, long-distance transport of $\mathrm{K}^{+}$occurs freely in both xylem and phloem. Thus, $\mathrm{K}^{+}$is readily exported from the older to the youngest expanded and expanding tissues where it is required in osmotic adjustment as well as in enzyme activation, protein synthesis, photosynthesis, and other metabolic processes. Phosphorus is also commonly retranslocated from old tissue to supply the requirements of developing organs. In contrast, $\mathrm{Ca}^{2+}$ has very limited mobility in the phloem. A high percentage of $\mathrm{Ca}^{2+}$ is firmly bound in structural constituents and tends to be retained in the older tissues.

Availability of nutrients, as well as their uptake, translocation, and partitioning, depends on the concentration and composition of solutes in the external medium, along with other environmental factors. Competition for uptake and transport sites at the plasma membrane have been reported between $\mathrm{K}^{+}$and $\mathrm{Ca}^{2+}, \mathrm{K}^{+}$and $\mathrm{NH}_{4}{ }^{+}$, and $\mathrm{Ca}^{2+}$ and $\mathrm{Mg}^{2+}$ (Grattan and Grieve, 1994; Marschner, 1995). Under saline conditions, the presence of excessive concentrations of $\mathrm{Na}^{+}, \mathrm{Ca}^{2+}, \mathrm{Mg}^{2+}, \mathrm{Cl}^{-}$, and $\mathrm{SO}_{4}{ }^{2-}$ in the external media may reduce nutrient availability, inhibit nutrient uptake, and saturate binding sites. Competition and interactions between $\mathrm{Cl}^{-}$and $\mathrm{NO}_{3}^{-}$,

Received for publication 5 Nov. 1998. Accepted for publication 19 May 1999. Use of a company or product name is given for the convenience of the reader and does not imply endorsement of the product by the USDA to the exclusion of others that may also be suitable. We are indebted to Phyllis Nash for statistical analysis and to Donald A. Layfield for mineral ion analysis. James A. Poss, Terence J. Donovan, and John H. Draper provided skilled technical assistance. This research was supported by the California Department of Water Resources (DWR B-59922), Project Manager, Fawzi Karajeh. The cost of publishing this paper was defrayed in part by the payment of page charges. Under postal regulations, this paper therefore must be hereby marked advertisement solely to indicate this fact.

'E-mail: cgrieve@ussl.ars.usda.gov.

${ }^{2}$ E-mail: mshannon@ussl.ars.usda.gov.
$\mathrm{Na}^{+}$and $\mathrm{Ca}^{2+}$, and $\mathrm{Na}^{+}$and $\mathrm{K}^{+}$in the substrate as well as within the plant frequently lead to ion imbalances that may result in nutrient deficiencies and/or ion toxicities.

Many Eucalyptus (L'Hér.) species have evolved on nutrientpoor soils of Australia. As a result, the eucalypts have developed mechanisms that enhance nutrient acquisition, uptake, use, and retention (Kriedemann and Cromer, 1996). In addition, species that are native to saline areas have developed ion exclusion or ion partitioning mechanisms to cope with potentially toxic elements, generally $\mathrm{Na}^{+}$and $\mathrm{Cl}^{-}$, that may occur in the root zone (Marcar and Termaat, 1990).

Eucalypts have been promoted as suitable species for environmentally acceptable strategies for the reuse of wastewater from domestic, industrial, and agricultural sources (Rhoades, 1989; Marcar et al., 1990). In many semiarid, salt-affected regions, drainage waters from irrigated agriculture are of moderate to high salinity. In the San Joaquin Valley of California, the performance of eucalypts has been assessed for tolerance to saline irrigation waters that contain a mixture of salts with $\mathrm{Na}^{+}, \mathrm{SO}_{4}{ }^{2-}, \mathrm{Cl}^{-}$, and $\mathrm{Mg}^{2+}$ as the predominant ions. Among the most promising clones were 4543, 4544, 4573 and 4590 (all E. camaldulensis) and 4501 (E. rudis) (Cervinka et al., 1995). Saplings of these selections, obtained by micropropagation, have been evaluated in greenhouse sand cultures irrigated with waters of mixed-salt salinity. The clones exhibited wide genotypic differences in salt tolerance, and could be divided into two distinct groups based on salinity levels that reduced biomass production by $50 \%\left(\mathrm{C}_{50}\right)$. The $\mathrm{C}_{50}$ values for clones 4543 , 4544 , and 4573 were $17.1,17.7$, and $16.4 \mathrm{dS} \cdot \mathrm{m}^{-1}$, respectively, whereas $\mathrm{C}_{50}$ values for 4501 and 4590 were significantly higher at 29.0 and $30.0 \mathrm{dS} \cdot \mathrm{m}^{-1}$, respectively (Grieve et al., 1999).

The objectives of the present study were to investigate the effect of mixed-salt salinity on ion relations in the above-ground organs of these eucalypts, and to determine if patterns of ion accumulation were related to the relative ranking of the clones based on salt tolerance $\left(\mathrm{C}_{50}\right.$ value $)$. A specific aim was to determine if the well-documented ability of the eucalypts to exclude $\mathrm{Na}^{+}$(Rogers, 1985) was affected by saline soil waters containing both $\mathrm{Cl}^{-}$and $\mathrm{SO}_{4}{ }^{2-}$. 


\section{Materials and Methods}

Five Eucalyptus clones, micropropagated by Twyford Plant Laboratories, Santa Paula, Calif., were grown in a greenhouse in Riverside, Calif.: 4501 (E. rudis), 4543, 4544, 4573, and 4590 (E. camaldulensis). One sapling of each clone was planted in each of 24 sand tanks on May 24, 1995. Plants were irrigated three times daily with a nutrient solution containing (in $\left.\mathrm{mol} \cdot \mathrm{m}^{-3}\right) 2.6 \mathrm{Ca}^{2+}, 1.6$ $\mathrm{Mg}^{2+}, 13.8 \mathrm{Na}^{+}, 3.0 \mathrm{~K}^{+}, 7.0 \mathrm{SO}_{4}{ }^{2-}, 7.0 \mathrm{Cl}^{-}, 5.0 \mathrm{NO}_{3}{ }^{-}, 0.17 \mathrm{KH}_{2} \mathrm{PO}_{4}$, $0.050 \mathrm{Fe}$ as sodium ferric diethylenetriamine pentaacetate (NaFeDTPA), $0.023 \mathrm{H}_{3} \mathrm{BO}_{3}, 0.005 \mathrm{MnSO}_{4}, 0.0004 \mathrm{ZnSO}_{4}, 0.0002$ $\mathrm{CuSO}_{4}$, and $0.0001 \mathrm{H}_{2} \mathrm{MoO}_{4}$ made up with city of Riverside municipal water. This base nutrient solution, electrical conductivity $\left(\mathrm{EC}_{\mathrm{i}}\right)=2 \mathrm{dS} \cdot \mathrm{m}^{-1}$, served as the control treatment. Each irrigation was $15 \mathrm{~min}$ duration, which allowed the sand to become completely saturated, after which the solutions drained to $765 \mathrm{~L}$ reservoirs for reuse in the next irrigation. Water lost by evapotranspiration was replenished automatically each day to maintain constant electrical conductivities in the solutions. Three weeks after the saplings were transplanted, treatments were imposed by adding salinizing salts to the nutrient solutions. Plant heights in $\mathrm{cm}$ ( \pm standard deviation) for the five clones at the start of salinization treatments were: $4501,50(4.9) ; 4543,68(5.0) ; 4544$, 56 (3.1); 4573, 51 (2.9); 4590, 66 (4.1).

The present study is part of a research project that includes growth analysis and determination of relative salt tolerance of the clones at eight salinity levels: $\mathrm{EC}_{\mathrm{i}}=2,4,8,12,16,20,24$, or 28 $\mathrm{dS} \cdot \mathrm{m}^{-1}$ (Grieve et al., 1999). For this report, however, ion relations of the clones are given for three treatments only: $\mathrm{EC}_{\mathrm{i}}=2,12$, or 28 $\mathrm{dS} \cdot \mathrm{m}^{-1}$. Concentrations of the salinizing ions for the $12 \mathrm{dS} \cdot \mathrm{m}^{-1}$ treatment were (in mol $\cdot \mathrm{m}^{-3}$ ) $\mathrm{Ca}^{2+} 12.6 ; \mathrm{Mg}^{2+} 10.0 ; \mathrm{Na}^{+} 88.5 ; \mathrm{Cl}^{-} 42.9$; and $\mathrm{SO}_{4}{ }^{2-} 44.9$, and for the $28 \mathrm{dS} \cdot \mathrm{m}^{-1}$ treatment: $\mathrm{Ca}^{2+} 14.0 ; \mathrm{Mg}^{2+}$ $31.8 ; \mathrm{Na}^{+} 282 ; \mathrm{Cl}^{-} 126$; and $\mathrm{SO}_{4}{ }^{2-} 118$. The experimental design was a randomized complete block with eight salinity treatments, five eucalyptus clones, and three replications.

Seven weeks after the initiation of salinization, plants were harvested by cutting about $10 \mathrm{~cm}$ above the surface of the sand. Each shoot was divided into four equal segments (lower, lowermiddle, upper middle, and upper). Leaf, branch, and stem tissues from each segment were separated, washed in deionized water, and dried in a forced-air oven at $70{ }^{\circ} \mathrm{C}$ for $72 \mathrm{~h}$. Tissues were weighed and ground to pass a 60 mesh screen.

During the study, daytime greenhouse air temperatures ranged from 22 to $43{ }^{\circ} \mathrm{C}$ (mean $\left.=32.5{ }^{\circ} \mathrm{C}\right)$; nighttime temperatures ranged from 14 to $22{ }^{\circ} \mathrm{C}$ (mean $=18.6^{\circ} \mathrm{C}$ ). Relative humidity ranged from $43 \%$ to $52 \%$, with a mean of $46.1 \%$ during the day and $49.2 \%$ during the night.

Ion ANALYSES. Total S, total $\mathrm{P} \mathrm{Ca}^{2+}, \mathrm{Mg}^{2+}, \mathrm{Na}^{+}$, and $\mathrm{K}^{+}$were determined on nitric-perchloric acid digests of the tissues by inductively coupled plasma optical emission spectrometry (ICPOES). Chloride was determined on nitric-acetic acid extracts by coulometric-amperometic titration. Ion partitioning to aboveground organs was determined by analyzing ion concentrations in leaves, stems, and branches from each of the four segments of each plant separately. To determine the average ion content $\left(\mathrm{C}_{\mathrm{avg}}\right)$ in the entire foliage of each plant, the concentration of each ion in the leaf samples of a segment was multiplied by the leaf dry weight in that segment:

$\mathrm{C}_{\text {avg }}=\sum\left(\mathrm{D}_{\mathrm{i}} \times \mathrm{C}_{\mathrm{i}}\right) / \mathrm{D}$

where $\mathrm{D}$ is the total leaf dry weight $(\mathrm{g}), \mathrm{D}_{\mathrm{i}}$ is dry weight of leaves in each segment, and $\mathrm{C}_{\mathrm{i}}$ is the concentration of the ion in the leaves in each segment (mmol $\mathrm{kg}^{-1}$ dry weight). Values from the four segments were then summed to give the average concentration of that ion in the entire foliage. Likewise, ion content in the complete stem and, where possible, the branches was also calculated. Complete data sets for the branches are not available, however, as in many of the lower segments, leaves were attached directly to the trunk.

Statistical analyses of the ion data were performed by analysis of variance with mean comparisons at the $95 \%$ level based on Tukey's studentized range test. SAS release version 6.12 was used. (SAS Institute, Inc., 1997).

\section{Results and Discussion}

Salinity studies are almost exclusively conducted with treatment salt concentrations, usually $\mathrm{NaCl}$ or fixed ratios of mixed salts. While this procedure is expedient, easily managed, and can be used to avoid sodicity in experiments conducted in soils, it is rarely realistic. In field situations where salinity problems prevail, root soil-water compositions fluctuate based on salinity of the irrigation water as influenced by soil chemistry reactions that include concentration dependent solubility, absorption, and precipitation. To simulate the changes that occur in soils, we used the model developed by Suarez and Simunek (1997) to predict the ion compositions that would occur in a typical San Joaquin Valley soil using typical drainage waters for irrigation. Treatment salt compositions were synthesized for the sand cultures based on these simulations.

Leaf loss was minimal during this study, therefore the ion concentrations reported are representative of the entire foliage. No visible symptoms of ion toxicities or nutrient deficiencies were observed. Gradients in ion partitioning to foliage and stem were assessed as a function of tissue age and position along the main shoot axis.

ION ACCUMULATION AND DISTRIBUTION. Calcium concentrations in the foliage of all clones were inversely correlated with salinity despite the increase in irrigation water $\mathrm{Ca}^{2+}$ from 2.6 to 14 $\mathrm{mol} \cdot \mathrm{m}^{-3}$ (Fig. 1A). At each salinity level, $\mathrm{Ca}^{2+}$ concentrations in leaves of clones 4543,4544 , and 4573 were not different from each other, but were significantly higher than 4501 at all salinity levels and than 4590 in the 2 and $12 \mathrm{dS} \cdot \mathrm{m}^{-1}$ treatments. Accumulation of $\mathrm{Ca}^{2+}$ in the stems followed similar patterns.

Calcium was highest in the oldest leaves in the lowest portion of the canopy, and its concentration progressively and significantly decreased with increasing leaf height on the main axis. This finding is consistent with the relative phloem-immobility of $\mathrm{Ca}^{2+}$ along with its tendency to be incorporated into structural components and retained in mature tissue (Dell, 1996; Grove et al., 1996; Marschner, 1995).

As salinity increased and the concentration of $\mathrm{Mg}^{2+}$ in the irrigation waters rose from 1.6 to $32 \mathrm{~mol} \cdot \mathrm{m}^{-3}$, leaf $\mathrm{Mg}^{2+}$ was unaffected in 4501, but decreased significantly in the other clones. At all salinities, $\mathrm{Mg}^{2+}$ in the foliage was at least twice as high as in the stems. (data not presented).

Regardless of salinity level, $\mathrm{Mg}^{2+}$ was retained in the oldest leaves, but was preferentially translocated to the uppermost stems of all E. camaldulensis clones. In contrast, $\mathrm{Mg}^{2+}$ tended to be more uniformly distributed throughout the foliage and stem sections of E. rudis.

The clones differed significantly with respect to leaf $\mathrm{Na}^{+}$ concentration (Fig. 1B). Leaf $\mathrm{Na}^{+}$in clones 4543, 4544, and 4573 increased from a mean of 15 to $85 \mathrm{mmol} \cdot \mathrm{kg}^{-1}$ dry weight as $\mathrm{Na}^{+}$ 
in the irrigation waters rose from 14 to $280 \mathrm{~mol} \cdot \mathrm{m}^{-3}$. Typically, eucalypts are nonaccumulator plants with respect to $\mathrm{Na}^{+}$, inasmuch as they drastically limit, but do not prevent, $\mathrm{Na}^{+}$uptake and transport to shoot tissues. At all salinity levels, Na was more effectively excluded from the leaves of these genotypes than from leaves of 4501 and 4590.

Clones 4501 and 4590 accumulated significantly more $\mathrm{Na}^{+}$in their leaves than the other clones and also exhibited a different type of $\mathrm{Na}^{+}$exclusion. At $2 \mathrm{dS} \cdot \mathrm{m}^{-1}, 4501$ and 4590 acted as $\mathrm{Na}^{+}$ includers as $\mathrm{Na}^{+}$in their leaves was an order of magnitude higher than in the irrigation waters. These leaf $\mathrm{Na}^{+}$concentrations $(\approx 200$ $\mathrm{mmol} \cdot \mathrm{kg}^{-1}$ dry weight) were relatively high compared to the other clones and to many plants in general. For example, leaf $\mathrm{Na}^{+}$in clover (Trifolium repens L.) and tomato (Lycopersicon esculentum Mill.) did not reach $200 \mathrm{mmol} \cdot \mathrm{kg}^{-1}$ dry weight until substrate salinities approached $12 \mathrm{dS} \cdot \mathrm{m}^{-1}\left(110 \mathrm{~mol} \cdot \mathrm{m}^{-3} \mathrm{NaCl}\right)$ (Noble and Shannon, 1988; Shannon et al., 1987); in poplar trees (Populus L. sp.), leaf $\mathrm{Na}^{+}$did not reach $200 \mathrm{mmol} \cdot \mathrm{kg}^{-1}$ dry weight until $\mathrm{EC}_{\mathrm{i}}=$ $7 \mathrm{dS} \cdot \mathrm{m}^{-1}$ (M.C. Shannon, unpublished). The Na-excluding capability of clones 4501 and 4590 only became apparent as salinity and $\mathrm{Na}^{+}$in the irrigation waters increased. The reason for the decrease in $\mathrm{Na}^{+}$accumulation is unclear, but this unusual response has been noted previously by Rogers (1985) who observed that leaf $\mathrm{Na}^{+}$in eucalypts, including E. camaldulensis, grown on a nonsaline site was frequently higher than in trees from a highly saline location. Rogers (1985) suggested that salt exclusion in the eucalypts may be a characteristic acquired with plant age and development. This hypothesis, however, does not explain the results of our experiment because clones were of identical age and similar development. Another hypotheses is that some eucalypts possess a mechanism for $\mathrm{Na}^{+}$exclusion or retranslocation that is
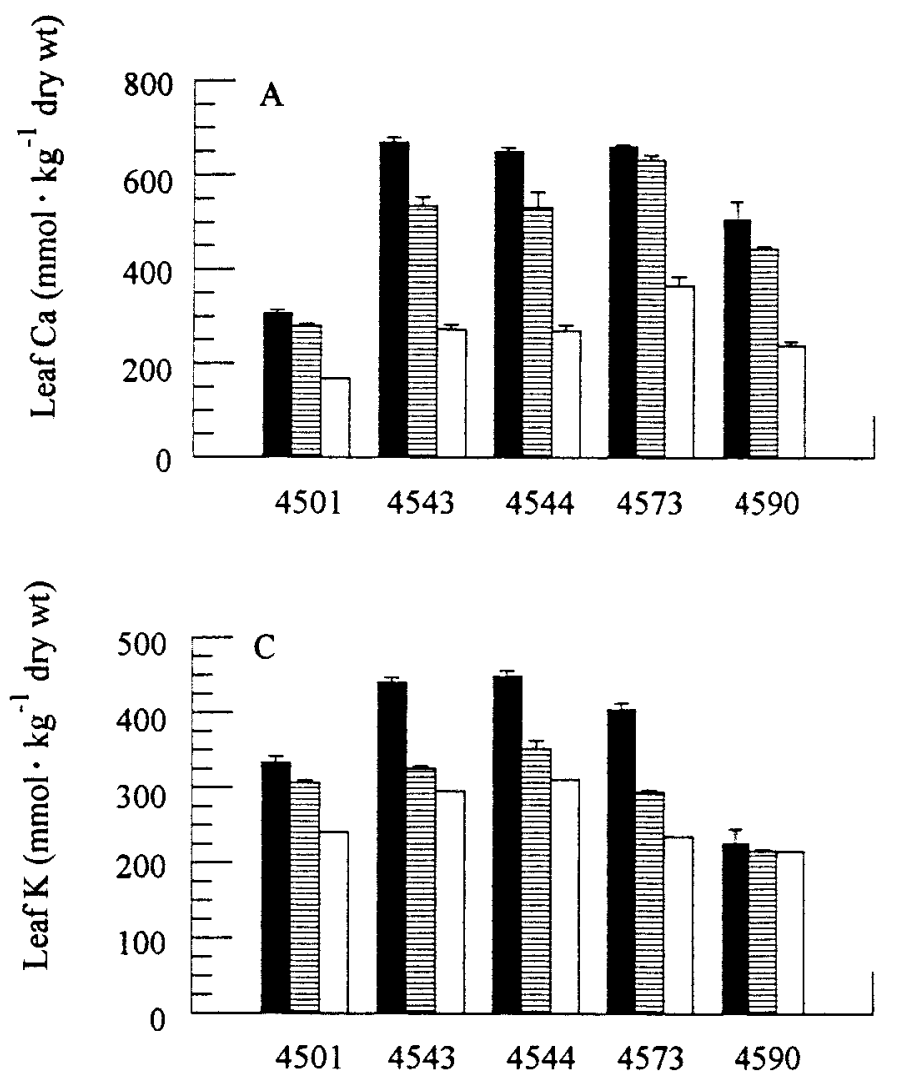

induced by salinity. In the present study, concentrations of both $\mathrm{Mg}^{2+}$ and $\mathrm{Ca}^{2+}$ in the irrigation waters increased with salinity. Therefore, interactions between $\mathrm{Na}^{+}$and these divalent cations in solution or in the shoot may not be ruled out as an explanation for the reduction of $\mathrm{Na}^{+}$in leaves of 4501 and 4590 . Sodium in stems of clones 4501, 4573, and 4590 significantly decreased with increasing stress, but salinity had no affect on $\mathrm{Na}^{+}$accumulation in stems of 4543 and 4544.

Under nonsaline conditions, leaf $\mathrm{K}^{+}$in clones 4501 and 4590 was significantly lower than in 4543, 4544, and 4573 (Fig. 1C). Increasing salinity reduced $\mathrm{K}^{+}$in leaves and stems of 4543,4544 , and 4573 and in leaves of 4501 , but had no effect on leaf and stem $\mathrm{K}^{+}$in 4590 and stem $\mathrm{K}^{+}$in 4501 . Reports of $\mathrm{K}^{+}$accumulation in organs of salt-stressed E. camaldulensis are inconsistent. For seedlings grown in greenhouse sand cultures irrigated with nutrient solutions salinized with $\mathrm{NaCl}$, Luangjame and Luukkanen (1991) observed a 3-fold decrease in leaf $\mathrm{K}^{+}$as $\mathrm{NaCl}$ concentration in the irrigation waters increased from $0 \%$ to $1.0 \%$. Further increases in substrate $\mathrm{NaCl}$, however, resulted in increases in leaf $\mathrm{K}^{+}$, and $\mathrm{K}^{+}$concentrations in leaves of plants grown in substrates containing $2 \% \mathrm{NaCl}$ were only $30 \%$ lower than in the nonsaline control treatment. Leaf $\mathrm{K}^{+}$in 2-year-old trees from a saline field site in tropical northern Australia increased initially as soil salinity rose from low to moderate concentrations, and then decreased at higher salinity (Sun and Dickinson, 1995). In contrast, leaf $\mathrm{K}^{+}$in E. camaldulensis seedlings grown under greenhouse conditions increased significantly with increasing substrate $\mathrm{NaCl}$ concentrations ( 0 to $500 \mathrm{~mm}$ ), although stem $\mathrm{K}^{+}$was unaffected by salinity (Prat and Fathi-Ettai, 1990). In the present study, salt stress tended to reduce $\mathrm{K}^{+}$concentrations, but did not inhibit its transport to the shoot apex. This response is commonly
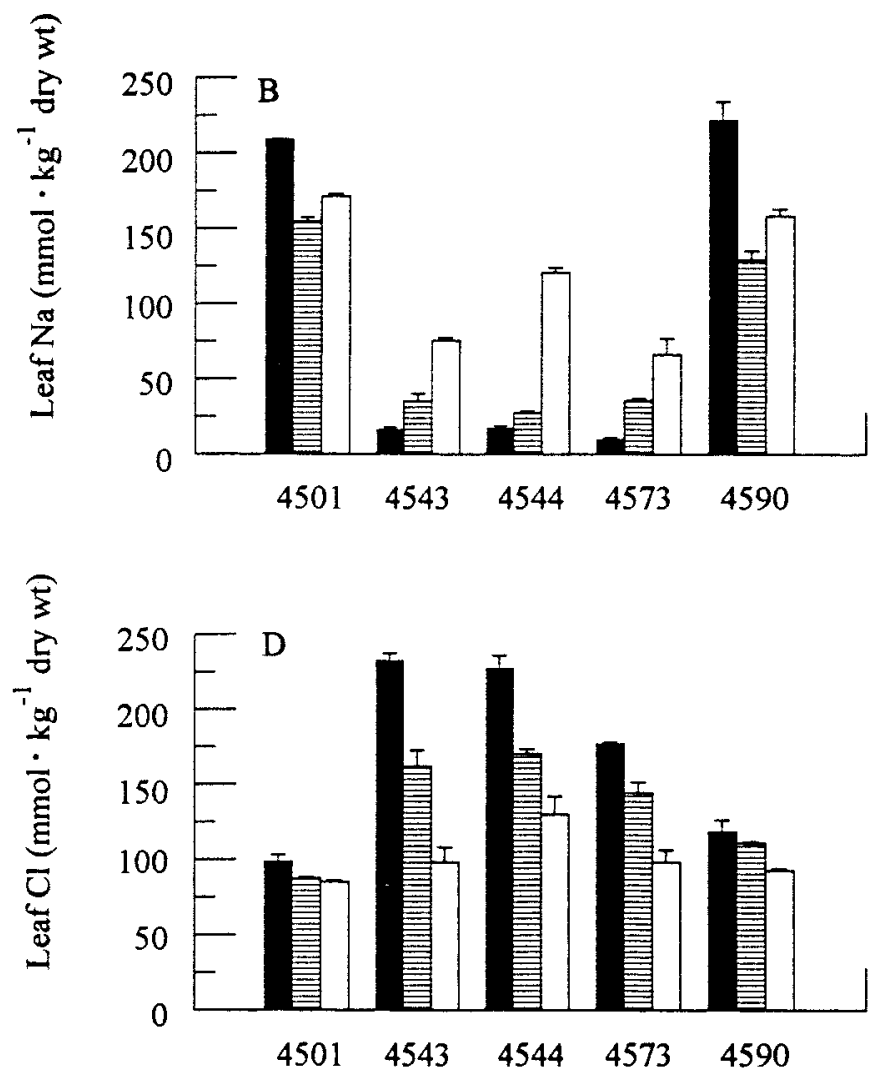

Fig. 1. Leaf (A), $\mathrm{Ca}^{2+},(\mathbf{B}) \mathrm{Na}^{+},(\mathbf{C}) \mathrm{K}^{+}$, and (D) $\mathrm{Cl}^{-}$concentrations in five Eucalyptus clones grown at three salinity levels [EC $=2$ (solid bars), 12 (hatched bars), or 28 (open bars) $\mathrm{dS} \cdot \mathrm{m}^{-1}$ ] for 7 weeks. Values are the means of three replications; error bars $=\mathrm{SE}$. 


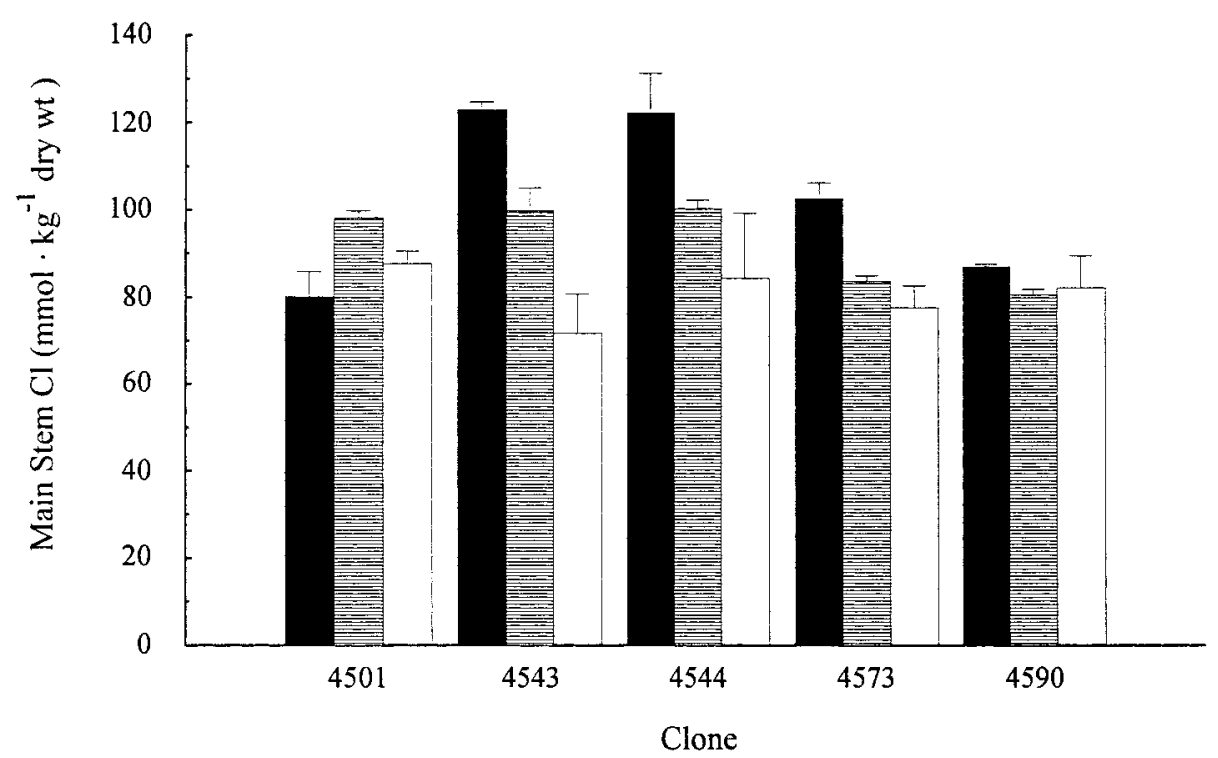

Fig. 2. Chloride concentrations in main stems of five Eucalyptus clones grown at three salinity levels $\left[\mathrm{EC}_{\mathrm{i}}=2\right.$ (solid bars), 12 (hatched bars), or 28 (open bars) $\left.\mathrm{dS} \cdot \mathrm{m}^{-1}\right]$ for 7 weeks. Values are the means of three replications; error bars $=\mathrm{sE}$.

observed in eucalypts as $\mathrm{K}^{+}$is readily retransported and moves freely from the older tissues towards the growing tips (Grove, 1996).

Total leaf $\mathrm{P}$ content in clones 4543, 4544, and 4573 was unaffected by salinity, but tended to increase in leaves of 4501 and 4590. Stem $P$ of all clones significantly increased with increasing salinity (data not presented). Under control conditions, total P distribution in the shoots followed the general trend reported for eucalypts (Grove et al., 1996) in that P was preferentially and significantly accumulated in the uppermost shoot organs.

Although $\mathrm{SO}_{4}{ }^{2-}$ in the irrigation waters rose from 7 to 118 $\mathrm{mol} \cdot \mathrm{m}^{-3}$, total $\mathrm{S}$ in the foliage and stems of all clones remained low ( $<75 \mathrm{mmol} \cdot \mathrm{kg}^{-1}$ dry weight). In leaves of 4501,4543 , and 4590 , total $\mathrm{S}$ was unaffected by treatment, but decreased significantly in leaves of 4544 and 4573 and in the stems of all clones. This response may be due in part to the negative interaction of substrate $\mathrm{Cl}^{-}$on $\mathrm{S}$ uptake, an effect that has been reported for herbaceous crops (Schnug, 1990).

Under control conditions, clones 4501 and 4590 accumulated significantly less $\mathrm{Cl}^{-}$in leaves and stems than 4543, 4544, and 4573. As $\mathrm{Cl}^{-}$in the irrigation waters increased from 7 to 126 mol $\cdot \mathrm{m}^{-3}$, leaf $\mathrm{Cl}^{-}$in all clones decreased (Fig. 1D). Stem $\mathrm{Cl}^{-}$in 4543,4544 , and 4573 tended to decrease with increasing salinity, but this effect was significant for 4543 only (Fig. 2). The ability of eucalypts to restrict $\mathrm{Cl}^{-}$uptake and accumulation in leaf tissue is well-documented (Sun and Dickinson, 1995). Rogers (1985) reported that leaf $\mathrm{Cl}^{-}$in $E$. camaldulensis remained unchanged at about $4.8 \mathrm{mg} \cdot \mathrm{g}^{-1}$ dry weight $\left(\approx 135 \mathrm{mmol} \cdot \mathrm{kg}^{-1}\right)$ as $\mathrm{Cl}^{-}$in perched water tables at plantation sites rose from $<100$ to nearly 8000 $\mathrm{mg} \cdot \mathrm{L}^{-1}$. From the results of a hydroponic experiment, Luangjame and Luukkanen (1991) found that leaf $\mathrm{Cl}^{-}$in E. camaldulensis seedlings increased as external $\mathrm{NaCl}$ rose from $0 \%$ to $1 \%$, then decreased by nearly $35 \%$ as $\mathrm{NaCl}$ increased to $1.5 \%$. In the present study, decreases in $\mathrm{Cl}^{-}$concentration in response to salinity may also have been the result of the inherent $\mathrm{Cl}^{-}$excluding ability of Eucalyptus coupled with the antagonistic effect of increasing levels of $\mathrm{SO}_{4}{ }^{2-}$ in the irrigation waters. Reports of the competitive inhibition of $\mathrm{Cl}^{-}$uptake by anions, including $\mathrm{SO}_{4}{ }^{2-}$, have been reviewed by Fixen (1993). Reduction of leaf and shoot $\mathrm{Cl}^{-}$with increasing salinity and root zone $\mathrm{Cl}^{-}$may also be the result of other, as yet unidentified, ion interactions.

In conclusion, gradients in ion concentration varied not only among above-ground components of the five Eucalyptus clones, but also with respect to the position of those components on the main axis. Salinity significantly affected ion concentration in the components and partitioning to tissues of different ages. Regardless of salinity level, ion concentration was higher in foliar tissue than in other shoot organs.

Leaf-ion accumulation patterns revealed significant differences among the clones. Based on ion relations, of the four $E$. camaldulensis clones, three (4543, 4544, and 4573) formed a coherent group, whereas clone 4590 (E. camaldulensis) was more closely and significantly allied with clone 4501 (E. rudis). Under control conditions, 4501 and 4590 (Group 2) accumulated significantly more $\mathrm{Na}^{+}$and less $\mathrm{K}^{+}, \mathrm{Ca}^{2+}$, and $\mathrm{Cl}^{-}$in leaves than 4543, 4544, and 4573 (Group 1). All clones showed a strong capacity to limit $\mathrm{Cl}^{-}$to the foliage and stem despite increases in external $\mathrm{Cl}^{-}$. The groups differed most notably in patterns of $\mathrm{Na}^{+}$accumulation. Group 1 clones limited leaf $\mathrm{Na}^{+}$under control conditions. As salinity increased to 28 $\mathrm{dS} \cdot \mathrm{m}^{-1}$, their leaf $\mathrm{Na}^{+}$gradually increased, but remained well below external $\mathrm{Na}^{+}$concentration. In contrast, $\mathrm{Na}^{+}$was more readily translocated to the leaves of 4501 and 4590 under control conditions, but these genotypes apparently possessed the ability to restrict $\mathrm{Na}^{+}$accumulation in the leaves as salinity increased. These five eucalyptus clones have also been divided into the same discrete classes with respect to differences in leaf morphology, growth, and relative salt tolerance. Based on biomass production, Group 2 clones were more tolerant to mixed-salt salinities than Group 1 (Grieve et al., 1999). Although the factors that contribute to the superior salt tolerance of clones 4501 and 4590 are unknown, their performance did not appear to be adversely affected by relatively high $\mathrm{Na}^{+}$concentrations in shoot tissues. The $\mathrm{Na}^{+}: \mathrm{K}^{+}$relations in the tolerant clones suggest these genotypes may be examples of natrophilic species which tend to accumulate $\mathrm{Na}^{+}$in the shoot where it may be used for osmotic adjustment and where it may replace $\mathrm{K}^{+}$(Marschner, 1995). In response to mixed-salt salinity containing both $\mathrm{Cl}^{-}$and $\mathrm{SO}_{4}{ }^{2-}$, the five eucalyptus clones exhibited unusual $\mathrm{Na}^{+}$and $\mathrm{Cl}^{-}$accumulation patterns that warrant further investigation.

\section{Literature Cited}

Cervinka, V., K. Grimes, M. Martin, R. Munoz, C. Finch, D. Krietemeyer, F. Menezes, and D. Peters. 1995. Agroforestry as a method of salt and selenium management on irrigated land. Amer. Soc. Agr. Eng. Paper 95-2366.

Dell, B. 1996. Diagnosis of nutrient deficiencies in eucalypts, p. 417440. In: P.M. Attiwill and M.A. Adams (eds.). Nutrition of eucalypts. CSIRO, Collingwood VIC, Australia.

Fixen, P.E. 1993. Crops responses to chloride. Adv. Agron. 50:107-150. Grattan, S.R. and C.M. Grieve 1994. Mineral nutrient acquisition and response by plants grown in saline environments, p. 203-226. In: M. Pessarakli (ed.). Handbook of plant and crop stress. Marcel Dekker, New York

Grieve, C.M., M.R. Guzy, J.A. Poss, and M.C. Shannon. 1999. Screen- 
ing eucalyptus clones for salt tolerance. HortScience (in press).

Grove, T.S., B.D. Thomson, and N. Malajczuk. 1996. Nutritional physiology of eucalypts: Uptake, distribution and utilization, p. 77-108. In: P.M. Attiwill and M.A. Adams (eds.). Nutrition of eucalypts. CSIRO, Collingwood VIC, Australia.

Kriedemann, P.E. and R.N. Cromer. 1996. The nutritional physiology of the eucalypts-Nutrition and growth, p. 109-121. In: P.M. Attiwill and M.A. Adams (eds.). Nutrition of eucalypts. CSIRO, Collingwood VIC, Australia.

Luangjame, J. and O. Luukkanen. 1991. Salinity effects on nutrient balance in Eucalyptus camaldulensis, p. 686-698. In: A.P.G. Schönau (ed.). The role of eucalypts. vol. 2. Proc. Symp. Intensive For. Durban, S. Africa.

Marcar, N.E., K.G. Eldridge, V.J. Hartney, and B.J. Myers. 1990. Tree species for woodlots: Future cultivars, p. 23-30. In: M. Dale (ed.). Proc. Woodlots Wkshp., Ser. 32. Mildura Function Ctr., Dept. Agr. Rural Affairs, VIC, Australia.

Marcar, N. E. and A. Termaat. 1990. Effects of root-zone solutes on Eucalyptus camaldulensis and Eucalyptus bicostata seedlings: Responses to $\mathrm{Na}^{+}, \mathrm{Mg}^{2+}$ and $\mathrm{Cl}^{-}$. Plant and Soil 125:245-254.

Marschner, H. 1995. Mineral nutrition of higher plants. Academic Press, London.

Noble, C.L. and M.C. Shannon. 1988. Salt tolerance selection of forage legumes using physiological criteria, p. 989-994. In: S.K. Sharma,
P.V. Sabe, S.C. Bhargava, and P.K. Agrawal (eds.). Proc. Congr. Plant Physiol, New Delhi, India.

Prat, D. and R.A. Fathi-Ettai. 1990. Variation in organic and mineral components in young Eucalyptus seedlings under saline stress. Physiol. Plant. 79:479-486.

Rhoades, J.D. 1989. Intercepting, isolating, and reusing drainage waters for irrigation to conserve water and protect water quality. Agr. Water Mgt. 16:37-52.

Rogers, A.L. 1985. Foliar salt in eucalyptus species. Austral. For. Res. 15:9-16.

SAS Inst., Inc. 1997. SAS/STAT software: Changes and enhancements through release 6.12. SAS Inst., Cary, N.C.

Schnug, E. 1990. Sulfur nutrition and quality of vegetables. Sulfur Agr. 14:3-7.

Shannon, M.C., J.W. Gronwald, and M. Tal. 1987. Effects of salinity on growth and accumulation of organic and inorganic ions in cultivated and wild tomato species. J. Amer. Soc. Hort. Sci. 112:416-423.

Suarez, D.L. and J. Simunek. 1997. UNSATCHEM: Unsaturated water and solute transport model with equilibrium and kinetic chemistry. Soil Sci. Soc. Amer. J. 61:1633-1646.

Sun, D. and G.R. Dickinson. 1995. Salinity effects on tree growth, root distribution and transpiration of Casuarina cunninghamiana and $E u$ calyptus camaldulensis planted on a saline site in tropical north Australia. For. Ecol. Mgt.. 77:127-138. 